\title{
KETIDAKPUASAN TERHADAP CITRA TUBUH DAN KEJADIAN FEMALE ATHLETE TRIAD (FAT) PADA REMAJA PUTRI
}

\author{
Budiar Ningrum Yuliana, Fillah Fithra Dieny ${ }^{*}$ \\ Program Studi Ilmu Gizi Fakultas Kedokteran Universitas Diponegoro \\ J1.Dr.Sutomo No.18, Semarang, Telp (024) 8453708, Email : gizifk@ undip.ac.id
}

\begin{abstract}
Background : Body image concerns in female adolescents who want a slim body shape with low body weight may influence female athlete triad (FAT). FAT is three rellated condition, eating disorders, menstrual dysfunction and low bone mass.The aimed of this study to describe body image dissatisfaction and prevalence of the female athlete triad among female adolescents.

Methods : Descriptive research, was conducted at SMA N 1 Semarang with 91 female adolescents as subjects selected by proportional stratified random sampling method. Data includes identity, body weight, body height, percent body fat, and bone mass. Body image assessment was measured by Body Shape Questionnaire (BSQ). Assessment of nutritional status was measured by z-score BMI/A and percent body fat, percent body fat was measured by a body fat analyzer. Assessment of eating disorder was obtained by eating disorder diagnostic scale (EDDS). Measurement of menstrual dysfunction used a questionnaire. Measurement of bone mass used quantitative ultrasound bone densitometry.

Results : Subjects had a body image dissatisfaction were 42 subjects (46.2\%). Eighteen subjects (19.8\%) had Eating Disorder Not Otherwise Specified (EDNOS). Subject had a menstrual dysfunction 25 subjects (27.5\%). Subject had low bone mass were 23 subjects (25.3\%). Subject had female athlete triad (FAT) were 2 subjects $(2.2 \%)$.

Conclusions : Subjects with a body image dissatisfaction is $46.2 \%$ of, and the prevalence of FAT at SMA N 1 Semarang $2.2 \%$.

Keywords : Female adolescent; body image; eating disorder; menstrual dysfunction; low bone mass; female athlete triad.
\end{abstract}

\begin{abstract}
ABSTRAK
Latar Belakang : Kekhawatiran citra tubuh pada remaja putri yang menginginkan bentuk tubuh ramping dengan berat badan kurang dapat mempengaruhi terjadinya female athlete triad (FAT). FAT merupakan tiga kondisi yang saling berkaitan, yaitu penyimpangan perilaku makan, gangguan menstruasi, dan kepadatan tulang rendah. Tujuan penelitian mengetahui gambaran ketidakpuasan terhadap citra tubuh dan prevalensi female athlete triad pada remaja putri.

Metode : Penelitian ini merupakan penelitian deskriptif bertempat di SMA Negeri 1 Semarang. Jumlah sampel 91 subjek yang dipilih dengan metode propotional stratified random sampling. Data penelitian meliputi identitas, berat badan, tinggi badan, persen lemak tubuh, dan kepadatan tulang. Penilaian citra tubuh menggunakan Body Shape Questionaire (BSQ). Penilaian status gizi menggunakan z-score IMT/U dan persen lemak tubuh, pengukuran persen lemak tubuh menggunakan body fat analyzer. Penilaian penyimpangan perilaku makan menggunakan eating disorder diagnostic scale (EDDS). Penilaian gangguan menstruasi menggunakan kuesioner. Penilaian kepadatan tulang menggunakan quantitative ultrasound bone densitometry.

Hasil : Subjek yang merasa tidak puas terhadap citra tubuhnya (merasa gemuk) sebanyak 42 subjek (46.2\%). Delapan belas subjek (19.8\%) mengalami Eating Disorder Not Otherwise Specified (EDNOS). Subjek dengan gangguan menstruasi sebanyak 25 subjek (27.5\%). Subjek dengan kepadatan tulang rendah 23 subjek (25.3\%). Pada penelitian ini ditemukan subjek yang mengalami female athlete triad (FAT) sebanyak 2 subjek (2.2\%).

Simpulan : Sebanyak 46.2\% subjek memiliki ketidakpuasan citra tubuh, dan prevalensi FAT di SMA N 1 Semarang sebesar $2.2 \%$.

Kata Kunci : Remaja putri; citra tubuh; gangguan makan; gangguan menstruasi; kepadatan tulang; female athlete triad.

\section{PENDAHULUAN}

Masa remaja merupakan salah satu periode pertumbuhan yang terjadi antara usia 10-19 tahun. Pada masa remaja terjadi perubahan-perubahan, baik secara fisiologis, psikologis maupun kognitif

di mana seorang anak akan menjadi dewasa muda. ${ }^{1}$ Kekhawatiran terhadap citra tubuh (body image) merupakan masalah umum yang terjadi selama masa remaja, terutama pada remaja putri. Citra tubuh yaitu 1) persepsi ukuran tubuh (kebenaran
\end{abstract}


mengenai persepsi ukuran tubuh seseorang seperti keyakinan bahwa ukuran tubuhnya lebih besar daripada ukuran tubuhnya yang sebenarnya), 2) komponen subyektif (kepuasan terhadap ukuran tubuh seseorang, kegelisahan dan perhatian mengenai ukuran tubuhnya atau bagian tubuh tertentu), 3) dilihat dari aspek perilaku (menghindar dari situasi yang dapat menyebabkan kegelisahan terhadap citra tubuhnya ). ${ }^{12}$

Banyak remaja yang menganggap diri mereka memiliki berat badan lebih meskipun berat badan yang sebenarnya adalah normal. Data dari Youth Risk Behavior Survey (YRBS) menemukan sebanyak 30\% siswi SMA menyatakan diri mereka memiliki berat badan lebih, meskipun pada faktanya hanya $13,5 \%$ yang benar-benar memiliki berat badan lebih.,

Adanya kekhawatiran terhadap citra tubuh pada remaja, terutama remaja putri yang menginginkan bentuk tubuh ramping dengan berat badan kurang dapat mempengaruhi terjadinya perilaku pola makan yang tidak sehat dan membatasi asupan dengan ketat sehingga dapat terjadi penyimpangan perilaku makan. Penelitian di SMA 70 Jakarta menunjukan $11,8 \%$ remaja putri mengalami anoreksia nervosa, $23 \%$ mengalami bulimia nervosa, 5\% mengalami BED, dan $48,5 \%$ mengalami EDNOS. ${ }^{13}$ Adanya penyimpangan perilaku makan diketahui berkaitan dengan gangguan menstruasi, yang terjadi karena adanya gangguan fungsi dari hipotalamus dan pituitari yang dipengaruhi oleh kurangnya jumlah leptin akibat dari pembatasan asupan, terutama lemak. ${ }^{4,10}$

Gangguan menstruasi disebabkan oleh menurunnya produksi hormone estrogen, dimana dikaitkan dengan penurunan berat badan atau malnutrisi pada wanita. Penelitian yang dilakukan pada siswi SMA Negeri 9 Semarang pada tahun 2006 menunjukkan sebesar 4\% mengalami polimenore dan $17,3 \%$ mengalami oligomenore. ${ }^{26}$

Hormon esterogen memiliki peran dalam proses mineralisasi tulang dan menghambat resorbsi tulang. Rendahnya esterogen berhubungan dengan rendahnya kepadatan mineral tulang dan meningkatkan risiko kepadatan tulang rendah. ${ }^{3-5,9}$ Penelitian yang dilakukan pada 74 siswi berusia 14-18 tahun di SMA Negeri Semarang belum ditemukan mengalami osteoporosis, namun sebanyak $28,6 \%$ mengalami osteopenia. ${ }^{27}$

Tiga gangguan yang saling berkaitan, yaitu penyimpangan perilaku makan, gangguan menstruasi, dan kepadatan tulang rendah disebut dengan Female Athlete Triad (FAT). FAT ini sering kali dialami oleh atlet putri yang menginginkan bentuk tubuh yang indah dan berat badan yang ringan untuk mempertahankan penampilan yang optimal, namun saat ini bukan hanya pada atlet putri saja yang dapat mengalaminya, remaja putri non-atlet juga bisa mengalami FAT. ${ }^{5,7}$ Hasil penelitian yang dilakukan antara siswa atlet dan siswa non-atlet di sekolah swasta di Midwest mendapatkan persentase yang mengalami FAT pada atlet $35 \%$ dan pada non-atlet $19 \%$. $^{8}$

Berdasarkan latar belakang tersebut perlu dilakukan penelitian untuk mendeskripsikan female athlete triad yang terjadi pada remaja putri di SMA Negeri 1 Semarang. Penelitian dilakukan ditempat tersebut karena dilihat dari letak sekolah yang berada dipusat kota, dimana para remaja putri lebih mudah mengakses informasi, mengikuti trend, lebih mudah terpengaruh terhadap fashion dan penilaian terhadap citra tubuh. Hal tersebut dapat membuat mereka lebih rentan mengalami body image negatif.

\section{METODE PENELITIAN}

Penelitian ini dilakukan di SMA Negeri 1 Semarang pada bulan Juli dan Agustus 2013. Penelitian ini merupakan penelitian deskriptif dan termasuk dalam ruang lingkup ilmu gizi masyarakat. Subjek pada penelitian ini adalah 91 siswa putri yang dipilih dengan menggunakan metode propotional stratified random sampling, dengan kriteria inklusi, yakni siswi putri berusia 15-18 tahun, tidak absen selama pengambilan data, bersedia menjadi responden, dan kooperatif.

Penelitian ini menggambarkan status gizi subjek, penilaian mengenai citra tubuh, penyimpangan perilaku makan, gangguan menstruasi, kepadatan tulang dan kejadian female athlete triad (FAT). Status gizi merupakan keadaan tubuh yang diakibatkan oleh keseimbangan antara asupan zat gizi dengan kebutuhan. Pengukuran status gizi subjek menggunakan IMT/U dengan kriteria interpretasi status gizi yang digunakan melalui z-score remaja putri, dengan kategori status gizi kegemukan (obesity) $>+2 \mathrm{SD}$, kelebihan berat badan (overweight) $>+1 \mathrm{SD}$, normal $-1 \mathrm{SD}-+1 \mathrm{SD}$, kurus (thinness) $<-2 \mathrm{SD}$, sangat kurus (severe thinness) <3SD. Berdasarkan persen lemak tubuh akan dikonversikan menggunakan grafik persen lemak tubuh berdasarkan usia dan jenis kelamin, dengan kategori underfat persentil $<5$, normal persentil $\geq 5$ $\leq 85$, overfat persentil $>85-\leq 95$, dan obese $>95$. $^{11}$ Pengukuran berat badan dan persen lemak tubuh 
menggunakan Body Fat Analyzer Omron dan pengukuran tinggi badan menggunakan microtoice $200 \mathrm{~cm}$ dengan ketelitian $0,1 \mathrm{~cm}$.

Citra tubuh merupakan persepsi remaja terhadap penampilan bentuk tubuhnya. ${ }^{21}$ Citra tubuh sangat berpengaruh pada sikap seseorang dalam menurunkan berat badan. Umumnya upaya penurunan berat badan dilakukan karena adanya citra tubuh negatif, yang merupakan perasaan tidak puas terhadap bentuk dan ukuran tubuh, sedangkan citra tubuh positif adalah rasa percaya diri seseorang karena merasa nyaman atau tidak masalah dengan keadaan tubuhnya, baik bentuk maupun ukuran tubuh. Penilaian mengenai citra tubuh menggunakan kuesioner Body Shape Questionaire (BSQ) yang berisi 34 pertanyaan mengenai kepuasan subjek terhadap bentuk tubuhnya. Hasil skor citra tubuh kemudian diinterpretasikan dalam empat kategori yaitu puas (no concern, skor <110), ketidakpuasan ringan (mild alteration, skor $>110-\leq 138$ ), ketidakpuasan sedang (moderate alteration, skor $>138-\leq 167$ ), dan ketidakpuasan berat (severe alteration, skor $>167) .{ }^{28}$

Penyimpangan perilaku makan adalah kebiasan makan yang tidak normal dan berhubungan dengan kebiasan penyalahgunaan obat, termasuk berpuasa, melakukan binge eating dan purging, anoreksia nervosa, bulimia nervosa dan atau menggunakan laksatif, diuretik, dan pil diet. Penilaian mengenai penyimpangan perilaku makan menggunakan eating disorder diagnostic scale (EDDS). Penilaian ini dapat dikategorikan menjadi anoreksia nervosa, bulimia nervosa, binge eating disorder (BED), dan eating disorder not otherwise specified (EDNOS). Pengkategorian penyimpangan perilaku makan didasarkan pada nilai yang ada dalam kuesioner tersebut. ${ }^{14}$

Gangguan menstruasi adalah ketidaknormalan status menstruasi yang dialami seseorang. Penilaian gangguan menstruasi menggunakan kuesioner. Pertanyaan didalam kuesioner tersebut meliputi usia pertama mengalami menstruasi, frekuensi, dan siklus menstruasi. Pengkategorian gangguan menstruasi, yaitu tidak terjadi gangguan apabila subjek mengalami haid 10-13 kali dalam setahun dan siklus menstruasi antara 21-35 hari. Primary amenorrhea apabila tidak mengalami menstruasi sampai usia 16 tahun. Secondary amenorrhea apabila subjek tidak mengalami menstruasi selama 3 bulan atau lebih setelah mengalami menstruasi pertama kali. Oligomenorrhea apabila siklus menstruasi subjek >35 hari namun kurang dari 3 bulan. Polymenorrhea apabila siklus menstruasi pendek, yaitu siklus menstruasi kurang dari 22 hari. $^{5,8}$

Kepadatan tulang rendah adalah keadaan dimana terdapat rendahnya massa tulang dan penurunan mikroarsitektural dari jaringan tulang yang menyebabkan peningkatan kerapuhan tulang dan meningkatnya risiko patah tulang. Penilaian kepadatan tulang menggunakan quantitative ultrasound bone densitometry. Pengkategorian kepadatan tulang subjek sebagai berikut normal apabila $T$-score $-1 \leq \mathrm{SD}<2,5$. Osteopenia apabila $T$-score $-2,5 \mathrm{SD}<-1$. Osteoporosis apabila $T$-score $\mathrm{SD}<-2,5 .{ }^{16}$ Female athlete triad (FAT) merupakan tiga kondisi yang saling berkaitan, yaitu penyimpangan perilaku makan, gangguan menstruasi, dan kepadatan tulang rendah yang terjadi pada subjek. ${ }^{5,8}$

Analisis data menunjukan hasil distribusi dan frekuensi. Data yang disajikan penelitian ini meliputi data frekuensi kategori status gizi subjek baik berdasarkan $z$-score IMT/U maupun persen lemak tubuh, frekuensi kategori penilaian citra tubuh, frekuensi kategori penyimpangan perilaku makan, frekuensi mengenai status menstruasi, frekuensi kategori kepadatan tulang, dan frekuensi kategori female athlete triad.

\section{HASIL PENELITIAN}

Subjek pada penelitian ini adalah 91 siswi yang berusia 15-18 tahun.

\section{Karakteristik Subjek Penelitian}

Tabel.1 Karakteristik Subjek Penelitian

\begin{tabular}{lccc}
\hline \multicolumn{1}{c}{ Karakteristik Subjek } & Minimum & Maksimum & Rerata \pm SD \\
\hline Usia (Tahun) & 15.23 & 17.56 & $16.12 \pm 0.41$ \\
Berat Badan $(\mathrm{Kg})$ & 38.1 & 113.6 & $53.73 \pm 1.20$ \\
Tinggi Badan $(\mathrm{cm})$ & 145.2 & 170 & $156.05 \pm 5.47$ \\
Persen Lemak Tubuh $(\%)$ & 18.10 & 39.80 & $26.15 \pm 4.11$ \\
Kepadatan Tulang $($ T-score $)$ & -3.4 & 1.8 & $-0.50 \pm 0.91$ \\
IMT/U (z-score) & -2.18 & 4.11 & $0.19 \pm 1.19$ \\
\hline
\end{tabular}


Tabel.1 menyajikan rerata usia, berat badan, tinggi badan, persen lemak tubuh, kepadatan tulang, dan z-score IMT/U subjek penelitian. Nilai rerata pada persen lemak tubuh seluruh subjek adalah $26.15 \% \pm 4.11$ dengan nilai tertinggi $39.80 \%$ dan nilai terendah $18.10 \%$. Nilai rerata kepadatan tulang seluruh subjek adalah $0.50 \pm 0.911$ dengan nilai tertinggi 1.8 dan nilai terendah -3.4 .

\section{Status Gizi}

Status gizi pada subjek penelitian yang mengalami kelebihan berat badan (overweight) 12 subjek (13.2\%) dan 8 subjek (8.8\%) mengalami kegemukan (obese), selain itu ditemukan pula subjek dalam kategori kurus sebanyak 14 subjek $(15.4 \%)$ dan 1 subjek (1.1\%) sangat kurus.

Tabel 2. Distribusi frekuensi menururt status gizi IMT/U (z-score)

\begin{tabular}{lcc}
\hline \multicolumn{1}{c}{ Kategori } & Frekuensi & Persentase (\%) \\
\hline Kegemukan & 8 & 8.8 \\
Kelebihan berat badan & 12 & 13.2 \\
Normal & 56 & 61.5 \\
Kurus & 14 & 15.4 \\
Sangat Kurus & 1 & 1.1 \\
\hline \multicolumn{1}{c}{ Total } & $\mathbf{9 1}$ & $\mathbf{1 0 0}$ \\
\hline
\end{tabular}

\section{Persen Lemak Tubuh}

Berdasarkan distribusi frekuensi z-score IMT/U masih ditemukan subjek dengan kategori kurus dan sangat kurus, namun pada pengukuran persen lemak tubuh tidak ditemukan subjek yang underfat. Sebanyak 11 subjek (12.1\%) mengalami overfat, dan sebanyak 4 subjek (4.4\%) mengalami obese.

Tabel 3. Distribusi frekuensi persen (\%) lemak tubuh

\begin{tabular}{lccc}
\hline & Kategori & Frekuensi & Persentase (\%) \\
\hline Obese & 4 & 4.4 \\
Overfat & 11 & 12.1 \\
Normal & Total & 76 & 83.5 \\
\hline \multicolumn{2}{r}{} & $\mathbf{9 1}$ & $\mathbf{1 0 0}$ \\
\hline
\end{tabular}

\section{Citra Tubuh}

Berdasarkan hasil pengukuran citra tubuh didapatkan subjek dengan citra tubuh positif (puas) sebanyak 49 subjek (53.8\%), sedangkan subjek dengan citra tubuh negatif sebanyak 42 subjek $(46.2 \%)$.

Tabel 4. Distribusi frekuensi menurut citra tubuh

\begin{tabular}{lcc}
\hline \multicolumn{1}{c}{ Kategori } & Frekuensi & Persentase (\%) \\
\hline puas (no concern) & 49 & 53.8 \\
Ketidakpuasan ringan (mild alteration) & 37 & 40.7 \\
Ketidakpuasan sedang (moderate alteration) & 4 & 4.4 \\
Ketidakpuasan berat (severe alteration) & 1 & 1.1 \\
\hline \multicolumn{1}{c}{ Total } & $\mathbf{9 1}$ & $\mathbf{1 0 0}$ \\
\hline
\end{tabular}

Berdasarkan Tabel 5 menunjukkan sebanyak 42 subjek (46.2\%) mengalami ketidakpuasan citra tubuh, dimana masih merasa dirinya gemuk atau kelebihan berat badan, padahal sebanyak 27 subjek yang mengalami ketidakpuasan citra tubuh tersebut sudah berstatus gizi normal. 
Tabel 5. Distribusi citra tubuh subjek berdasarkan status gizi $z$-score IMT/U

\begin{tabular}{|c|c|c|c|c|c|c|c|c|c|}
\hline \multirow[t]{3}{*}{ Status Gizi } & \multicolumn{8}{|c|}{ Citra Tubuh } & \multirow{3}{*}{$\begin{array}{c}\text { Total } \\
\text { n }\end{array}$} \\
\hline & \multicolumn{2}{|c|}{ Puas } & \multicolumn{2}{|c|}{$\begin{array}{l}\text { Ketidakpuasa } \\
\text { n ringan }\end{array}$} & \multicolumn{2}{|c|}{$\begin{array}{l}\text { Ketidakpuasa } \\
\text { n sedang }\end{array}$} & \multicolumn{2}{|c|}{$\begin{array}{c}\text { Ketidakpuasa } \\
\text { n berat }\end{array}$} & \\
\hline & $\mathbf{n}$ & $\%$ & $\mathbf{n}$ & $\%$ & $\mathbf{n}$ & $\%$ & $\mathbf{n}$ & $\%$ & \\
\hline Kegemukan & 2 & 2.2 & 6 & 6.6 & - & - & - & - & 8 \\
\hline $\begin{array}{l}\text { Kelebihan berat } \\
\text { badan }\end{array}$ & 3 & 3.3 & 6 & 6.6 & 2 & 2.2 & 1 & 1.1 & 12 \\
\hline Normal & 29 & 31.9 & 25 & 27.5 & 2 & 2.2 & - & - & 56 \\
\hline Kurus & 14 & 15.4 & - & - & - & - & - & - & 14 \\
\hline Sangat kurus & 1 & 1.1 & - & - & - & - & - & - & 1 \\
\hline Total & 49 & 53.8 & 37 & 40.6 & 4 & 4.4 & 1 & 1.1 & 91 \\
\hline
\end{tabular}

Penyimpangan Perilaku Makan

Berdasarkan kuesioner penilaian

penyimpangan perilaku makan didapatkan

sebagian besar subjek (80.2\%) tidak mengalami penyimpangan perilaku makan (normal), namun sebanyak 18 subjek (19.8\%) mengalami Eating

Disorder Not Otherwise Specified (EDNOS).

Tabel 6. Frekuensi distribusi penyimpangan perilaku makan

\begin{tabular}{|c|c|c|}
\hline Kategori & Frekuensi & $\begin{array}{l}\text { Persentase } \\
(\%)\end{array}$ \\
\hline Normal & 73 & 80.2 \\
\hline $\begin{array}{l}\text { Eating Disorder Not Otherwise Specified } \\
\text { (EDNOS) }\end{array}$ & 18 & 19.8 \\
\hline
\end{tabular}

Pada penelitian ini didapatkan subjek penyimpangan perilaku makan sebanyak 18 subjek dengan ketidakpuasan citra tubuh yang mengalami (19.8\%), dapat dilihat dari tabel 7 .

Tabel 7. Frekuensi penyimpangan perilaku makan terhadap citra tubuh

\begin{tabular}{lccccc}
\hline \multirow{1}{*}{ Citra Tubuh } & \multicolumn{3}{c}{ Penyimpangan Perilaku Makan } & \multirow{2}{*}{ Total } \\
& \multicolumn{2}{c}{ Normal } & \multicolumn{2}{c}{ EDNOS } & \\
\cline { 2 - 5 } & $\mathrm{n}$ & $\%$ & $\mathrm{n}$ & $\%$ & $\mathrm{n}$ \\
\hline Puas & 43 & 47.3 & 6 & 6.6 & 49 \\
Ketidakpuasan Ringan & 28 & 30.7 & 9 & 9.9 & 37 \\
Ketidakpuasan Sedang & 2 & 2.2 & 2 & 2.2 & 4 \\
Ketidakpuasan Berat & - & - & 1 & 1.1 & 1 \\
\hline \multicolumn{1}{c}{ Total } & $\mathbf{7 3}$ & $\mathbf{8 0 . 2}$ & $\mathbf{1 8}$ & $\mathbf{1 9 . 8}$ & $\mathbf{9 1}$ \\
\hline
\end{tabular}

\section{Gangguan Menstruasi}

Seluruh subjek mengalami menstruasi pertama pada usia kurang dari 16 tahun sehingga tidak ditemukan risiko primary amenorrhea. Sebagian besar subjek, yaitu 66 subjek $(72.5 \%)$ tidak mengalami gangguan menstruasi/normal, namun ditemukan subjek dengan gangguan menstruasi pada kategori oligomenorrhea sabanyak 7 subjek (7.7\%), dan polymenorrhea sebanyak 18 subjek (19.8\%).

Tabel 8. Frekuensi distribusi status menstruasi

\begin{tabular}{lcc}
\hline \multicolumn{1}{c}{ Kategori } & Frekuensi & Presentase (\%) \\
\hline Usia Awal Menstruasi & & \\
$<16$ tahun & 91 & 100 \\
$>16$ tahun & 0 & 0 \\
Mengalami menstruasi 3 bulan terakhir & 91 & 100 \\
Ya & & \\
\hline
\end{tabular}




\begin{tabular}{lcc}
\hline Tidak & 0 & 0 \\
Gangguan Menstruasi & & \\
Tidak ada gangguan (21-35 hari) & 66 & 72.5 \\
Oligomenorrhea $(>35$ hari) & 7 & 7.7 \\
Polymenorrhea $(<21$ hari) & 18 & 19.8 \\
\hline \multicolumn{1}{c}{ Total } & $\mathbf{9 1}$ & $\mathbf{1 0 0}$ \\
\hline
\end{tabular}

\section{Kepadatan Tulang}

Hasil kepadatan tulang diperoleh sebagian besar subjek termasuk kategori normal, yaitu sebanyak 68 subjek (74.7\%). Namun, ditemukan sebanyak 22 subjek $(24.2 \%)$ mengalami osteopenia, dan 1 subjek (1.1\%) mengalami osteoporosis.

Tabel 9. Frekuensi distribusi kepadatan tulang

\begin{tabular}{ccc}
\hline Kategori & Frekuensi & Presentase (\%) \\
\hline Normal $(-1 \leq \mathrm{SD}<2,5)$ & 68 & 74.7 \\
Osteopenia $(-2,5 \mathrm{SD}<-1)$ & 22 & 24.2 \\
Osteoporosis (SD $<2,5)$ & 1 & 1.1 \\
\hline Total & $\mathbf{9 1}$ & $\mathbf{1 0 0}$ \\
\hline
\end{tabular}

\section{Female Athlete Triad}

Kejadian FAT pada penelitian ini sudah ditemukan meskipun prevalensinya masih kecil, yaitu sebanyak 2 subjek (2.2\%). Kedua subjek yang mengalami FAT diketahui mengalami ketidakpuasan terhadap citra tubuh, dan memiliki status gizi lebih.

Tabel 10. Frekuensi distribusi female athlete triad (FAT)

\begin{tabular}{lll}
\hline Kategori & Frekuensi & $\begin{array}{l}\text { Persentase } \\
(\mathbf{\%})\end{array}$ \\
\hline Penyimpangan perilaku makan + gangguan menstruasi & 4 & 4.4 \\
Gangguan menstruasi + kepadatan tulang rendah & 8 & 8.8 \\
$\begin{array}{l}\text { Penyimpangan perilaku makan, gangguan menstruasi, } \\
\text { dan kepadatan tulang rendah }\end{array}$ & 2 & 2.2 \\
\hline
\end{tabular}

\section{PEMBAHASAN \\ Status Gizi}

Pada pengukuran z-score IMT/U masih ditemukan subjek dengan status gizi kategori kurus dan sangat kurus, sedangkan pengukuran status gizi menggunakan persen lemak tubuh tidak ditemukan subjek dengan underfat. Pengukuran $z$ score IMT/U merupakan salah satu cara untuk mengetahui status gizi remaja yang dilihat dari berat dan tinggi badan berdasarkan umur, namun tidak menunjukkan komposisi tubuh secara jelas, sedangkan pengukuran persen lemak tubuh untuk mengetahui status gizi diperlukan untuk melihat komposisi lemak tubuh pada remaja putri. Persentase lemak tubuh dapat mempengaruhi kematangan seksual pada remaja putri. ${ }^{25}$

Selama pubertas, remaja putri mengalami pertambahan lemak. Setelah masa percepatan tinggi badan, terjadi akumulasi lemak lebih cepat dan ekstensif, yaitu keseluruhan lemak sekitar 25\% dari berat badan. Akumulasi lemak pada remaja putri terdapat pada anggota gerak maupun tubuhnya, terutama tubuh bagian bawah dan paha bagian belakang. ${ }^{25}$ Hipotesis dari para ilmuwan bahwa munculnya menstruasi dipengaruhi oleh persentase lemak tubuh dikaitkan dengan berat tubuh total. Munculnya menstruasi pertama dibutuhkan minimal $17 \%$ berat tubuh perempuan terdiri dari lemak tubuh, dan persentase lemak tubuh yang dibutuhkan untuk menjaga keteraturan menstruasi selanjutnya adalah sekitar $22 \%$. $^{1,10}$

\section{Citra Tubuh}

Secara umum, para remaja putri kurang puas dengan bentuk tubuhnya dan memiliki citra tubuh yang lebih negatif selama pubertas. Remaja putri merasa tidak puas dengan bentuk tubuhnya sehubungan dengan meningkatnya jumlah lemak, sehingga memotivasi para remaja putri untuk memiliki tubuh yang sangat kurus. ${ }^{1}$ Ketidakpuasan citra tubuh tidak hanya dialami oleh subjek dengan kelebihan berat badan, namun juga terjadi pada subjek dengan status gizi normal. Hal ini 
menunjukkan bahwa meskipun subjek telah memiliki berat badan ideal namun subjek menganggap bahwa ukuran tubuhnya lebih besar dari ukuran sebenarnya, dimana hal ini dapat menjadi berbahaya jika remaja putri dengan status gizi normal namun mengalami ketidakpuasan citra tubuh dapat mempengaruhi perilaku tidak tepat dalam mencapai bentuk tubuh ideal. ${ }^{22}$

Pertanyaan pada kuesioner yang diajukan didominasi oleh pertanyaan yang menyatakan ketidakpuasan atau adanya kekhawatiran terhadap kelebihan berat badan. Pada hasil penelitian didapatkan sebanyak 15 subjek merasa tidak puas terhadap citra tubuh dikarenakan memiliki status gizi lebih, ini mengartikan bahwa subjek tersebut memiliki kekhawatiran terhadap kelebihan berat badan dan menginginkan bentuk tubuh yang ideal. Sedangkan subjek dengan status gizi kurang sebanyak 15 subjek memiliki kepuasan citra tubuh ini mengartikan bahwa tidak adanya kekhawatiran terhadap kelebihan berat badan.

Berdasarkan penelitian yang dilakukan di Yogyakarta menyatakan bahwa remaja putri sangat menyukai bentuk tubuh dengan berat badan yang rendah dibandingkan bila berat badan yang besar, karena konsep ideal tubuh seorang wanita adalah memilki tubuh tinggi langsing, karena paradigma menjadi seorang putri yang cantik berarti memiliki tubuh yang langsing. ${ }^{22,29}$

\section{Penyimpangan Perilaku Makan}

Eating Disorder Not Otherwise Specified (EDNOS), yaitu merupakan gangguan perilaku makan atau atipikal dengan perilaku makan yang tidak teratur, termasuk salah satu kategori anoreksia nervosa, yaitu adanya ketakutan kenaikan berat badan atau menjadi gemuk, adanya ketidakpuasan terhadap bentuk tubuh, dan termasuk salah satu kriteria bulimia nervosa, yaitu adanya perasaan tidak dapat mengendalikan porsi makan, melakukan olahraga berat untuk menurunkan berat badan. ${ }^{15,20}$

Dari 18 subjek yang mengalami gangguan perilaku makan kategori EDNOS, diantaranya sebanyak 12 subjek memiliki penilaian citra tubuh yang negatif dimana subjek memiliki kekhawatiran terhadap kelebihan berat badan sehingga terjadi penyimpangan perilaku makan dengan alasan sering melewatkan sarapan pagi dan makan malam dengan alasan tidak sempat, malas, takut gemuk, dan lainnya.

Penyimpangan perilaku makan sering ditemui pada remaja putri dan dewasa muda perempuan yang merasa tidak puas dengan penampilan dirinya sendiri. Hal tersebut cenderung membuat mereka melakukan pengontrolan berat badan dan dapat terjadi penyimpangan perilaku makan. ${ }^{19}$ Komponen utama dari penyimpangan perilaku makan yang dapat dikaitkan dengan adanya ketidapuasan citra tubuh adalah termasuk masalah berat badan, masalah bentuk badan, masalah makan, dan pengendalian makan; penyimpangan perilaku makan juga berhubungan dengan gangguan gambaran tubuh, dan berat badan yang naik turun, sehingga timbul kekhawatiran jika terjadi kelebihan berat badan. ${ }^{18}$

\section{Gangguan Menstruasi}

Pada penelitian ini terdapat sebanyak 18 subjek $(19.8 \%)$ mengalami gangguan menstruasi berupa polimenore dan sebanyak 7 subjek (7.7\%) mengalami gangguan menstruasi berupa oligomenore. Penelitian yang dilakukan pada siswi SMA Negeri 9 Semarang pada tahun 2006 menunjukkan sebesar $4 \%$ mengalami polimenore dan $17,3 \%$ mengalami oligomenore. ${ }^{26}$

Gangguan menstruasi dapat diakibatkan karena terjadi penekanan hipotalamus-pituitariovarium dimana kondisi ini disebut dengan Functional hypothalamic amenorrhea. Faktorfaktor yang dapat mempengaruhi Functional hypothalamic amenorrhea yang dapat menyebabkan gangguan menstruasi berhubungan dengan gangguan makan, ketersediaan energi yang kurang, penurunan berat badan, aktivitas yang berlebihan, kelebihan berat badan dan faktor stres. Pada remaja putri dengan keadaan tersebut dapat berpengaruh terhadap adanya gangguan menstruasi.

Functional hypothalamic amenorrhea ditandai dengan penekanan gonadotropinreleasing hormone $(\mathrm{GnRH})$. Penekanan $\mathrm{GnRH}$ mempengaruhi beberapa hormon yang kemudian mempengaruhi pelepasan luteinizing hormone (LH) dan follicle stimulating hormone (FSH), estrogen dan progesteron. Penurunan frekuensi pengeluaran LH dan FSH dari kelenjar pituitari yang kemudian terjadi penekanan pada ovarium sehingga dapat terjadi gangguan menstruasi. ${ }^{9}$

\section{Kepadatan Tulang}

Sebanyak 23 subjek memiliki kepadatan tulang yang rendah. Kepadatan tulang adalah hasil dari proses dinamis dari pembentukan tulang dan pembongkaran tulang yang disebut bone remodeling. ${ }^{30}$ Osteopenia apabila tidak ditangani dengan baik dapat berisiko mengalami osteoporosis atau patah tulang. ${ }^{24}$ Osteopenia pada remaja putri dapat dipengaruhi oleh beberapa faktor seperti gaya hidup kurang aktif fisik, berat 
badan yang rendah, serta asupan zat gizi pembentuk tulang yang rendah. ${ }^{17}$

Kepadatan tulang dipengaruhi oleh beberapa faktor risiko diantaranya yang tidak dapat dikendalikan, yaitu jenis kelamin, umur, ras, riwayat keluarga, tipe tubuh, dan menopause pade wanita dewasa. Sedangkan faktor risiko yang dapat dikendalikan diantaranya adalah gaya hidup, aktivitas fisik, pola makna seimbang, kebiasaan merokok, minuman beralkohol, asupan kalsium, dan kecukupan vitamin D. Kepadatan tulang juga berkorelasi antara usia dan penyakit, usia pada saat menstruasi, durasi penyakit, indeks massa tubuh (IMT), dan massa tubuh tanpa lemak. ${ }^{6,10}$ Penurunan massa tulang berhubungan dengan adanya gangguan menstruasi, dimana terjadi gangguan hipotalamus-pituitari-ovarium. Hal ini dapat mempengaruhi berkurangnya produksi estrogen yang mempunyai pengaruh signifikan dalam metabolisme mineral tulang. ${ }^{16}$

Kurangnya estrogen pada masa remaja dapat menyebabkan penurunan kepadatan tulang dan dapat berakibat osteoporosis. Estrogen berperan dalam proses mineralisasi tulang dan menstimulasi aktivitas osteoblas, dan penurunan estrogen meningkatkan aktivitas osteoklas, dimana terjadi ketidakseimbangan pembentukan kembali tulang dan lebih banyak terjadi resorpsi sehingga menyebabkan kepadatan tulang rendah. ${ }^{16}$

\section{Female Athlete Triad (FAT)}

Kejadian FAT pada atlet banyak terjadi pada atlet dengan olahraga berat, dan yang mempertahankan bentuk tubuh ramping dengan berat badan rendah atau kurus, namun pada penelitian yang dilakukan terhadap remaja putri non-atlet ditemukan kejadian FAT terjadi pada remaja putri yang memiliki ketidakpuasan terhadap citra tubuh sehubungan dengan kelebihan berat badan sehingga subjek berusaha menurunkan berat badan untuk mendapatkan bentuk tubuh yang langsing.

FAT dapat terjadi pada remaja putri disebabkan karena kekhawatiran terhadap citra tubuh pada remaja putri yang menginginkan bentuk tubuh ramping dengan berat badan rendah dapat mempengaruhi terjadinya perilaku pola makan yang tidak sehat dan membatasi asupan yang ketat. ${ }^{4}$ Pada penelitian ini ditemukan 2 subjek (2.2\%) yang mengalami FAT, yaitu penyimpangan perilaku makan, gangguan menstruasi, dan kepadatan tulang rendah.

Subjek yang mengalami FAT pada penelitian ini memiliki ketidakpuasan terhadap citra tubuh dimana subjek merasa bahwa dirinya gemuk atau memiliki kelebihan berat badan. Hal tersebut dapat disebabkan karena subjek memiliki status gizi menurut IMT/U adalah overweight dan normal, sedangkan menurut pengukuran persen lemak tubuh subjek memiliki status gizi overfat dan obese.

Pembatasan asupan, terutama lemak dapat mempengaruhi jumlah leptin, hal ini dapat menekan hipotalamus untuk mengeluarkan gonadotropin releasing hormon $(\mathrm{GnRH}) .{ }^{1}$ Konsekuensi dari keadaan tersebut yang terjadi pada remaja putri dengan ketidakpuasan citra tubuh berupa gangguan menstruasi. Gangguan menstruasi terjadi karena adanya gangguan fungsi dari hipotalamus dan pituitari yang dapat menyebabkan menurunnya produksi hormon estrogen. Hormon estrogen memiliki peran yang besar untuk menjaga kekuatan kepadatan mineral tulang. Rendahnya estrogen berhubungan dengan rendahnya kepadatan mineral tulang dan meningkatkan risiko osteoporosis. ${ }^{3-5,9}$

\section{SIMPULAN}

Sebanyak $42 \quad(46.2 \%)$ mengalami ketidakpuasan terhadap citra tubuh, padahal 27 subjek diantaranya sudah memiliki status gizi normal. Delapan belas subjek (19.8\%) mengalami penyimpangan perilaku makan kategori Eating Disorder Not Otherwise Specified (EDNOS), subjek dengan gangguan menstruasi sebanyak 25 subjek (27.5\%), dan yang mengalami kepadatan tulang rendah sebanyak 23 subjek (25.3\%). Pada penelitian ini ditemukan pula subjek yang mengalami female athlete triad (FAT) yaitu kombinasi dari tiga keadaan yang saling berkaitan, yaitu penyimpangan perilaku makan, gangguan menstruasi, dan kepadatan tulang rendah sebanyak 2 subjek $(2.2 \%)$.

\section{DAFTAR PUSTAKA}

1. Santrock, John W. Remaja. Edisi 11. Jakarta: Erlangga;2007; 20; 84; 91-92

2. Spear, Bonnie. Nutrition in Adolescent. Krause's Food, Nutrition and Diet Therapy. Philadelpia. Saunders; 2004; 284-301; 365-366.

3. George, Jessica B. Edwards PHD, and Debra L. Franko PHD. Cultural Issues in Eating Pathology and Body Image Among Children and Adolescents. Journal of Pediatric Psychology 2010; 35:231-242.

4. Gray, Susan Hayden. Menstrual Disorders. Pediatrics in Review. 2013;34;6

5. Monica Klungland Torstveit, Jorunn SundgotBorgen. The Female Athlete Triad: Are Elite 
Athletes at Increased Risk?. Medicine \& Science in Sports \& Exercise. 2005.

6. Elaine Dennison, Judith Medley, Cyrus Cooper. Who is at Risk of Osteoporosis?. Women's Health Medicine 3:4.

7. Pettersson U, Stalnacke B, Ahlenius G, Henricksson-Larsen K, dan Lorentzo R. Low Bone Mass Density At Multiple Skeletal sites, including the appendicular skeleton in amenorrheic runners. Calsiferous Tissue International. 1999;64:125177.

8. Anne Z Hoch, DO., Nicholas M. Pajewski, PhD., LuAnn Moraski, DO., Guillermo F, Carrera, MD., Charles R. Wilson, MD., Raymond G. Hoffmann, $\mathrm{PhD}$. et al. Prevalence of the Female Athlete Triad In High School Athletes And Sedentary Students. Clin J Sport Med. 2009;5:421-428.

9. Catherine M., Gordon, M.D. Functional Hypothalamic Amenorrhea. N Engl J Med. 2010;363-365;71.

10. S. Bryn Austin, Sc.D., Najat J. Ziyadeh, M.P.H., Sameer Vohra, B.A., Sara Forman, M.D., Catherine M. Gordon, M.D., M.Sc., Lisa A. Prokop, B.A. Irregular Menses Linked to Vomiting in a Nonclinical Sample: Findings from the National Eating Disorders Screening Program in High Schools. Journal of Adolescent Health. 2008.42:450-457.

11. World Health Organization (WHO). Growth References 5-19 years for Adolescent. Diunduh dari http://www.who.int//growthreferences5-

19 yearsforadolescent.2007-pdf//. Pada tanggal 15 Mei 2013.

12. Heinberg L.J. Katherine C.W, J. Kevin. Body Image. Rickert VI. Adolescent Nutrition Assesment And Management : Chapman And Hall ; 1996. 136-156.

13. Putra WKY. Gambaran dan Faktor-Faktor yang Berhubungan dengan Kecenderungan Penyimpangan Perilaku Makan pada Siswi SMA N 70 Jakarta Selatan tahun 2008 (Skripsi). FKM UI. 2008

14. Stice, Eric, Christy F. Telch, Shireen L. Rizvi. Development and Validation of the Eating Disorder Diagnostic Scale: A Brief Self-Report Measure of Anorexia, Bulimia, and Binge-Eating Disorder. American Psychological Association, Inc. 2000. No. 2, 123-131.

15. Nelms, Marcia, Kathryn P. Sucher, Karen Lacey, Sara Long Roth. Nutrition Therapy and Pathophysiology. Second Edition. 2010;268-275.

16. Tamas Csermely, Laszlo Halvax, Miklos Vizer, Istvan Drozgyik, Peter Tamas, Peter Gocze, et al. Relationship between Adolescent Amenorrhea and Climacteric Osteoporosis. The European Menopause Journal. 2006; 368-374.

17. Sankaran Balu. Osteoporosis Clinical, Radiology, Histological, Assessment and an Experimental Study. New Delhi. 2000. P: 176-211.
18. Michelle T Barrack, Mitchell J Rauh, HavaShoshana Barkai, and Jeanne F Nichols. Dietary Restraint and Low Bone Mass in Female Adolescent Endurances Runner. Am J Clin Nutr. 2008;87:36-43.

19. Istiqomah NP. Hubungan Antara Faktor Eksternal dan Internal terhadap Kecenderungan Penyimpangan Perilaku Makan pada Atlet Wanita di SMP/SMA Negeri Ragunan Jakarta (Skripsi). FKMUI. 2009.

20. Lebrun, Connie. The Female Athlete Triad. Elsevier:Women's Health Medicine 3:3.

21. Stang, Jang and Story Mary. Guidelines for Nutrition Services. Department of Health and Human Services: US. 2005; 1-11; 101-102; 155.

22. Robles, Dalmas. Thinness and Beauty: When Food Becomes The Enemy. The International Journal of Research and Review. 2009; Vol 2; 1-9.

23. Dieny, Fillah Fithra. Citra Tubuh dan Perilaku Tidak Tepat dalam Pencapaian Bentuk Tubuh Ideal pada Siswi SMA di Semarang Tahun 2009. Semarang. Program Pasca Sarjana Universitas Diponegoro, 2009. (TESIS).

24. May-Coo Wang, Patricia B Crawford, Mark Hudes, Marta Van Luan, Kirstin Siemering, and Laura K Bachrach. Diet in Mid Puberty Predict Peak Bone Mass. Am J Clin Nutr 2003. Vol 77. P: 495-503.

25. Suandi, dr. I Kompiang Gede, SpA., Prof. dr. Soetjiningsih, SpA(K), IBCLC. Tumbuh Kembang Remaja dan Permasalahannya. Jakarta : Sagung Seto. 2004;23.

26. Anindita, Yotania Galuh. Hubungan Antara Asupan Serat dan Persentase Lemak Tubuh dengan Siklus Menstruasi pada Remaja Putri (Skripsi). 2010.

27. Maspaitela, Meidi Lidia. Hubungan Asupan Kalsium dan Fosfor, Indeks Massa Tubuh, Persen Lemak Tubuh, Kebiasaan Olahraga, Usia Awal Menstruasi dengan Kepadatan Tulang pada Remaja Putri (Skripsi). 2011.

28. Di Pietro $M$, and Da Silveira XD. Internal Validity, Dimentionaly and Performance of The Body Shape Questionnaire in A Group of Brazilian College Student. Brazilia Journal Psychiatry. 2008; no.3; page : $1-4$.

29. Ratri Mulatsih. Hubungan Antara Citra Tubuh dengan Status Gizi pada Remaja Putri di SMP N 8 Yogyakarta. Program Sarjana Universitas Gajah Mada; 2008.

30. Dana LC, Amy LM, Debra B, Gunnar BP. Weight Bearing Exercise and Markers of Bone Turnover in Female Athletes. Ohio: Journal Applied Physiology. 2001: 90, 565-570. 